„Tehetség, szorgalom, hivatás”

\author{
Tanulmánykötet
}

Kézirat lezárva: 2021. június 25. 
Kiadja:

a Magyar Rendészettudományi Társaság

Vám- és Pénzügyőri Tagozata

Szerkesztette:

Csaba Zágon és

Zsámbokiné Ficskovszky Ágnes

Felelős kiadó:

Szabó Andrea

ISBN: 978-615-81879-0-9

A mú szerzői jogilag védett. Minden jog, így különösen a sokszorosítás, terjesztés és fordítás joga fenntartva. A mű a kiadó írásbeli hozzájárulása nélkül részeiben sem reprodukálható, elektronikus rendszerek felhasználásával nem dolgozható fel, azokban nem tárolható, azokkal nem sokszorosítható és nem terjeszthetô. 
Szerzők

Lektorok

Lectori Salutem!

Tanulmányok

Christián László - Lippai Zsolt: Kakukktojás vagy új rendészeti alappillér?

Gonda Éva: Az Europol hospitáció hasznosítása a pénzügyi nyomozók képzése terén

Kakócz Krisztián - Vedó Attila: A toloncolás szabály- és szervezetrendszere a második világháború előtt

Kovács Gábor: A vezetői kompetenciák fejlesztésének lehetőségei a Rendészettudományi Kar hallgatóinak körében

Magasvári Adrienn: Egy új jogviszony „születése” - az adó- és vámhatósági szolgálati jogviszony vizsgálata ..

Molnár Katalin: Mi harminc? Tudománymetria helyett - Szerzőtársas játék................................ 87

Nyeste Péter: A modern bűnügyi hírszerzés modelljeinek fejlődése ............................................ 103

Pajor Andrea: Adóigazgatási tisztviselők képzése .

Sallai János - Borszéki Judit: Egy megvalósítható utópia? Közös munkanyelv keresése a nemzetközi rendőri együttmúködés kezdetén.

Suba László: Nyelvhelyesség a közszférában: Létkérdés vagy úri huncutság?

Szabó Andrea - Hájer Tamara: A vámfelsőoktatás uniós elismerési eljárásának elemei

Szlifka Gábor: Okos adózás, okos adóigazgatás - Minden ami okos, de mit is jelent pontosan?

Kutatási eredmények

Balla József - Kiss Lajos: A rendvédelmi szervező szakirányú továbbképzési szak indításának legfontosabb tapasztalatai.

Borzán Anita - Szekeres Bernadett: A digitalizáció hatása a gazdasági szakismeretek és a számvitel oktatására.

Duchon Jenő: Tanulási stílus és játékos típus összevetése felnőtteknél, az oktatási folyamat játékosítása céljából

Erdős Ákos - Somogyi Ágnes: Koffeinhasználat és koffeinhasználati zavar vizsgálata rendészeti hallgatók körében

Halasi Nóra: Feltáró kutatás a hivatástudat és motiváció jelentőségének vizsgálatára, a Hajdú-

Bihar Megyei Adó- és Vámigazgatóság személyi állományának összefüggésében 251 
DOI: $\underline{10.37372 / \mathrm{mrttvpt} .2021 .1 .4}$

\title{
Kovács Gábor*: A vezetői kompetenciák fejlesztésének lehetőségei a Rendészettudományi Kar hallgatóinak körében
}

\begin{abstract}
Absztrakt
A hallgatók felkészítése a rendészeti életpályára rendkívül összetett feladat, amelynek megvalósításban a Rendészettudományi Kar (kar) minden oktatója és minden alkalmazottja egyaránt részt vesz. A kar hivatásos állománya nem csak kiképez, oktat, nevel, hanem ezeken a folyamatokon belül kiemelt hangsúlyt helyez a hallgatók körében a vezetői kompetenciák kialakítására. Ebben a feladatban az oktatók és a hallgatók közötti széles körû, tudatos együttmúködés szükséges, amelynek néhány legfontosabb színtere és módszere jelen tanulmányban kerül összefoglalásra.
\end{abstract}

Kulcsszavak: Rendészettudományi Kar, vezetöi felkészités, jó gyakorlatok, vezetöi kompetenciák kialakitása, tisztjelölti felkészítés.

\begin{abstract}
Preparing students for a career in law enforcement is an extremely complex task. In the implementation, all lecturers and all employees of the Faculty of Law Enforcement are involved. The professional staff of the Faculty not only trains, educates, but also put emphasis on the development of leadership competencies among students within these processes. This task requires a wide range of conscious cooperation between lecturers and students. The most important scenes and methods of this cooperation are summarized in this essay.
\end{abstract}

Keywords: Faculty of Law Enforcement, preparing leaders, good practices, developing leadership competences, preparation of officer candidates.

\section{Bevezetés}

A Nemzeti Közszolgálati Egyetem Rendészettudományi Kara a magyar felsőoktatás olyan intézménye, ahol az államtudományi képzési területen - az alapképzés, a mesterképzés és a Rendészettudományi Doktori Iskola keretei között - folyik a különböző szakterületeken tevékenykedő leendő rendészeti vezetők és más szakemberek vezetôi felkészítése. A felsőfokú rendőrtisztviselôo ${ }^{139}$ és rendőrtiszti képzésben közel száz éve tradicionálisan fontos szerepet kap a vezetői felkészítés. ${ }^{140}$ Az intézmény működésének egyik kiemelt stratégiai célja az, hogy olyan jól felkészített vezetőket és szakembereket képezzen, akik rövid ideig

\footnotetext{
* Kovács Gábor, Prof. Dr., rendőr dandártábornok, tanszékvezető egyetemi tanár, Nemzeti Közszolgálati Egyetem Rendészettudományi Kar Rendészeti Vezetéstudományi Tanszék., https://orcid.org/0000-00021699-827X, kovacs.gabor@uni-nke.hu

139 SALLAI János: A magyar rendészeti képzés története 1922-2017.: Rendőr altiszt (tiszthelyettes) és rendőrtiszt képzés a XX-XXI században. In: Czene-Polgár Viktória - Zsámbokiné Ficskovszky Ágnes (szerk.) Mérföldkövek az adó- és vámigazgatás történetéből. Válogatott tanulmányok az évfordulók tükrében. Magyar Rendészettudományi Társaság Vám- és Pénzügyőri Tagozat, Bp., 2017. pp. 86-123.

140 SALLAI János: Rendőr altiszt- és tisztképzés a m. kir állami rendőrségnél az államosítás (1920) után. In: VARGA János (szerk.) A határrendészeti tisztképzés negyedszázada. Dialóg Campus Kiadó, Bp., 2017. pp. 239_ 253.
} 
tartó szakmai tapasztalat megszerzését követően, vezetőként és beosztottként egyaránt képesek lesznek a rájuk bízott feladatok ellátására, a szervezetek közvetlen vezetésére, a tevékenység irányítására, amely összhangban van a megrendelői igényekkel ${ }^{141}$ is. Ehhez a feladatkörhöz elkerülhetetlen az, hogy a különböző képzéseken végzett hallgatók megismerjék a vezetéselmélet alapjait, a vezetési folyamat elemeit, összetevőit, képesek legyenek rendszerekben gondolkodni, amennyiben szükséges műveleti törzsekben tevékenykedni. A felkészítés eredményeként feleljenek meg a rájuk bízott beosztotti-, beosztott vezetői- és felső vezetői feladatok ellátásával kapcsolatos elvárásoknak.

\section{A vezetéssel szemben támasztott általános követelmények}

A vezetéssel szemben támasztott legfontosabb követelmények a vezetéselméletben ható általános elvekre vezethetôk vissza ${ }^{142}$, amely elvek folyamatosan fejlődnek és hatásuk is folyamatos. Ezeket az elveket fel kell ismerni, a vezetőnek ezeket a hatásokat figyelembe kell vennie és érvényre kell juttatnia a vezetô-irányító munkája során. Ezen követelmények teljesítéséhez tartozó vezetői kompetenciák elsajátítása a Rendészettudományi Karon a képzések során megvalósul, a végzett hallgatók egy erős alappal felvértezve kezdik pályájukat, pályafutásuk során folyamatosan fejlődnek, majd a kellő gyakorlati vezetői tapasztalatot megszerezve ezek a magatartásminták mintegy beépülnek az illető személyiségébe, ez által vezetővé válnak.

\section{A vezetéssel szemben támasztott követelmények}

A vezetéssel szemben támasztott legfontosabb követelmények a következők lehetnek:

- A vezetés folyamatosságának követelménye azt jelenti, hogy a vezetésnek minden időben megszakításmentesnek kell lennie, a munkatársaknak és a vezető által irányított szervezetnek folyamatosan éreznie kell a vezetői figyelmet. A vezetőnek minden esetben gondoskodnia kell arról, hogy távolléte esetén is mindig legyen olyan kijelölt felelős személy, aki érdemben tudja helyettesíteni, és aki szükség esetén felelős döntéseket is meg tud hozni.

- A következő követelmény a szilárdság, amely azt jelenti, hogy a beosztott állomány és a szervezet a kiadott utasításokat és a meghatározott feladatokat határidőre, jó minőségben hajtja végre. Az utasítások, parancsok betartása és teljesítése első számú beosztotti kötelezettség. Annak behatárolása, hogy a törvényben meghatározottakat ki, mikor, hogyan hajtja végre.143 A vezetői döntést követően, a vezetőnek következetesen ki kell tartania az általa meghatározott feladat elvégzése mellett, folyamatosan keresnie kell azokat a megoldásokat, amelyekkel az adott feladat minél színvonalasabban, de ezzel együtt minél kevesebb energiaráfordítással legyen elvégezhető.

- A következetesség követelménye a vezető munkájában úgy nyilvánul meg, hogy a vezető a munkatársainak és szervezetének a teljesítményét mindig tárgyilagosan ítéli meg. A munkatársak ezáltal folyamatosan érzik azt, hogy munkájuk, tevékenységük

\footnotetext{
${ }^{141}$ BALLA József: A régi-új Határrendészeti Tanszéki Tanácsadó Testület, mint a megrendelői igények meghatározásának és támogatásának fóruma. Határrendészeti Tanulmányok, XIII. évfolyam 2016,/1. szám. pp. 66-83.

${ }^{142}$ KovÁCs Gábor: A rendészeti szervezetekben lejátszódó vezetési folyamatok. Dialóg Campus Kiadó, Bp., 2018. pp. 45-46.

${ }^{143}$ KOVÁCS István: Klasszikus vezetési funkciók a parancsuralmi rendszerben (állományvédelmi) ellenőrzés, és korrupciómegelőzés a helyi, és területi rendvédelmi szervek körében. Nemzeti Közszolgálati Egyetem, Bp., 2018. pp. 1-102.
} 
a szervezet eredményessége szempontjából fontos, valamint azt, hogy teljesítményüket folyamatos figyelem kíséri.

- Az előrelátás képessége azt jelenti, hogy a vezetőnek a várható feladatok végrehajtása során számolnia kell azokkal a következményekkel is, amelyek befolyásolják a szervezeti működést. Ezeket a zavaró tényezőket és hatásokat a vezetőnek megfelelő előrelátással ki kell küszöbölnie.

- A rugalmasság az a vezetői tulajdonság, amely során a vezető a bekövetkezett változásokra reagál. Amennyiben szükséges, a vezető döntéseit a kialakult helyzet függvényében megváltoztatja, ekkor figyelembe veheti munkatársai javaslatait, alkalmazkodva a megváltozott helyzethez és körülményekhez. Megjegyzendő, hogy a rugalmasság és a szilárdság egymással ellentétes követelmény, de a megfelelő arányt a jó vezetőnek fel kell ismernie és be kell tartania.

- A vezetô problémamegoldó képessége abban az esetben ideális, ha a vezetô és a munkatársai közösen dolgozzák ki az adott feladat megoldására vonatkozó alternatívákat és ezzel együtt azt az optimális megoldást, amelyik sikerre viszi a közös tevékenységet.

- A tervszerűség követelményének betartása érdekében a vezető olyan jó minőségű, színvonalas terveket készít, amelyeket szervezetével együtt, közösen, a szervezeti célok elérése érdekében tudnak megvalósítani. E mellett a tervszerűség azt is jelenti, hogy a munkavégzés tervszerűen folyik, a munkaterhek elosztása egyenlő mértékü, a munkatársak tevékenysége tervszerūen folyik.

- A vezetői kiszámíthatóság és a váratlanság követelménye. Alapvető vezetői feladat, hogy a vezető stabil, tervezhetô, kiszámítható munkakörnyezetet és munkafeltételeket biztosítson, hiszen ezek nagymértékben hozzájárulnak a munkahely támogató szervezeti kultúrájának kialakításához. A kiszámíthatóságra törekvő vezetői törekvés mellett az időszakonként alkalmazott váratlansági tényezőt is érvényre kell juttatni, hiszen ezzel a vezetői ellenőrzések hatékonysága megnövelhető. Ennek egyetlen célja van, az, hogy a munkavégzés akkor is rendben folyjon, amikor a vezetô fizikailag nincs jelen a munkakörnyezetben.144

\section{A vezetói tulajdonságok kialakitása}

Néhány évvel ezelőtt az egyetemi oktatói közösség körében vita alakult ki abban a kérdésben, hogy a Nemzeti Közszolgálati Egyetem Rendészettudományi Karán tanuló minden egyenruhát viselő hallgató kapjon-e vezetői felkészítést az alapképzésük során. A kiérlelt szakmai vita során az az álláspont vált általánosan elfogadottá, hogy minden hivatásrendi (függetlenül az adott szaktól, szakiránytól) hallgató előbb-utóbb vezetővé válhat, még abban az esetben is, ha a pályafutásának az első beosztásai még nem vezetői beosztások.

Maga a vezetôvé válás egy időben is elhúzódó folyamat, hiszen nem attól lesz valaki vezetô, hogy megkapja kinevezését, hanem attól, hogy az illető végig járja a vezetővé válás lépcsőit és annak teljes folyamatát. Ebben a felkészülésben be kell tartani a fokozatosság elvét, ügyelve arra, hogy a fiatal vezető megkapjon minden segítséget az adott szintű vezetôi munkakörben, és majd ha ott sikerrel teljesített és bizonyított, akkor léphet tovább a magasabb vezetési szintre.

144 CZUPRÁK Ottó - KovÁcs Gábor: A szervezetvezetés elmélete. Dialóg Campus Kiadó, Bp., 2017. p. 69. alapján 


\section{A sikeres vezetök legfontosabb tulajdonságai}

A Rendészettudományi Karon nem csak kiképzés, képzés, oktatás és nevelés folyik, hanem ezek a felkészítési módszerek együtt, egyfajta szinergiát alkotva komplexen hozzájárulnak a hallgatók vezetői személyiségjegyeinek a kialakításához. A három és négyéves hallgatói felkészítési időszak, a hallgatókkal való folyamatos törődés, általában elegendő a hallgatók személyiségének formálásához, a vezetői tulajdonságok biztos alapjainak lerakásához. ${ }^{145}$

Melyek a sikeres vezetők legfontosabb tulajdonságai, amelyek már a hallgatói, tisztjelölti időszakban kialakíthatók?

A kar minden oktatójának és minden alkalmazottjának a kiváló szakmai felkészültsége a záloga annak, hogy a rendészeti felsőoktatásban a hallgatóknak lehetőségük van a kiváló szintü, korsz̨erü és színvonalas szakmai tudás megszerzésére, az elméleti és gyakorlati ismeretek elsajátítására.

A fegyelem és az igényesség belülröl fakadó követelményének a kialakitása. A vezető legyen elsősorban saját magával, de munkatársaival szemben is követelménytámasztó, igényes, egyben rendszerető és fegyelmezett, igyekezzen a feladatokat a lehető legmagasabb színvonalon végrehajtani és végrehajtani. Ha valaki önmagától is meg tudja követelni a rendet, fegyelmet, akkor ez a tulajdonsága átsugárzik az adott vezető környezetére, segítve ezzel az írott és íratlan szabályok betartását.

Az együttmúkeödés képessége az alapvető vezetői tulajdonságok egyike, hiszen a legtöbb feladat közös tevékenységet igényel a szervezeti tagok részéről. A vezetői erények közé tartozik az, ha a vezető felismeri a szervezeti együttmûködésben rejlő lehetőségeket és azt, hogy a szervezet sikere közös siker, amely egyúttal az ő sikere is.

A szakmai- és vezetői szempontból jól felkészített vezető a munkatársai tiszteletét csak úgy vívhatja ki, hogy ha megfelelő empatikus készséggel és igazságérzettel rendelkęilk. Megfontolásra érdemes vezetői tanács az, hogy „Vezetőként és beosztottként is úgy bánj másokkal, ahogy szeretnéd, hogy veled is bánjanak".

A felelösségvállalás. A vezetői munkában a saját és a mások munkájáért érzett felelősség biztosítja a sikeres közös tevékenységet. A sikeres vezető felvállalja a munkatársai és a saját felelősségét az esetleges kudarcok elszenvedése során. Vezetőként úgy marad valaki hiteles, hogy minden esetben vállalja vezetői felelősségét, hiszen a vezető felelős azért, amit tett, és amit megtenni elmulasztott. Az egyszemélyi vezetés elve értelmében a szervezet vezetóje a szervezet jogszerű működéséért, illetve tevékenységéért teljes és oszthatatlan felelősséggel tartozik. ${ }^{146}$

A folyamatos tervezómunka, batározott tervek. A vezetői munka során a reális tervezés és a részletek átgondolása a sikeres vezetői tevékenység fontos jellemzője. Az egyes feladatok kivitelezése során megfelelő részletességgel szükséges átgondolni az egyes tevékenységeket, szakmai feladatokat. Kiemelt vezetői feladat a munkatársak tevékenységének

\footnotetext{
145 ERDŐS Ákos et al.: Új generáció a rendészeti felsőoktatásban. In: GAÁL Gyula - HAUTZINGER Zoltán (szerk.): Gondolatok a rendészettudományról. Magyar Rendészettudományi Társaság. Bp, 2019. pp. 89-102.

146 KOVÁCS István: Vezetői státusz, és kommunikáció a parancsuralmi rendszerben, különös tekintettel a Rendőri Hivatás Etikai Kódexére, valamint a vezetési stílusokra a Lasswell modell alapján. Magyar Rendészet, Budapest, 2018. 18. évfolyam 5. szám, pp. 177-196.
} 
összehangolása, motiválása, e mellett a vezetőnek biztosítania kell a feladat elvégzéshez szükséges különböző erőforrásokat.

A döntés meghozatalának képessége. A vezetőnek munkája során folyamatosan döntenie kell. Tartózkodnia szükséges a hirtelen meghozott, nem kellő alapossággal megalkotott döntésektől, de az sem szerencsés, ha a döntéshez szükséges minden információ bevárása miatt, a vezető késlekedik a döntéshozatallal. A karon folyó vezetés- és szervezéselméleti felkészítés kellő alapot és elméleti tudást biztosít az optimális vezetői döntések megalkotásához.

Példamutatás, példaadás. A vezető akarva-akaratlanul mintául szolgál munkatársai, beosztottjai számára. A példaadó viselkedés, a tisztelet, a visszafogott életvitel, a magas szintű munkamorál, az ápolt, rendezett megjelenés már önmagában megköveteli mások elismerését. ${ }^{147}$

A sikeres vezetők néhány legfontosabb tulajdonságának áttekintése után kijelenthető, hogy a Rendészettudományi Kar hallgatókkal foglakozó minden munkatársa arra törekszik, hogy ezeket a vezetói tulajdonságokat kialakítsa a tisztjelöltekben.

\section{A vezetői felkészítés fő színterei a Rendészettudományi Karon}

\section{A rendészeti alapkiképzés intenzív szakasza}

A Rendészettudományi Kar egyenruhás képzéseinek hallgatói részére az iskolarendszerű oktatás előtt a rendészeti szocializációs folyamat beindítására és az azzal kapcsolatos alapok elsajátítása céljából, öt hetes - az alakiképzés intenzív szakasza - időszak veszi kezdetét a bevonulást követően. ${ }^{148}$ Ezzel elindul az a szocializációs folyamat, amely a tanintézetben végigkíséri a tisztjelölteket egészen a tiszt rendfokozatba történő kinevezésig.

A hallgatói alapkiképzést a Kiképzési és Nevelési Osztály rendészeti kiképzői és gyakorlati oktatói vezetik. Az alapkiképzés intenzív szakaszában az elsőéves hallgatók tevékenységét a felsőbb éves hallgatói raj- és szakaszparancsnokok irányítják, ők segítőként, segéd foglakozásvezetőként vesznek részt a teljes alapkiképzésben. Ez a gyakorlási színhely kiváló lehetőséget teremt a felsőbb évesek számára a vezetői feladatok gyakorlására, és a vezetői tulajdonságok kialakítására. Az első éves hallgatók az első szemeszter befejezésekor tisztjelölti vizsgát tesznek, ahol bizonyítják felkészültségüket a félév során elsajátított rendészeti ismeretekből. ${ }^{149}$

\section{A ballgatói gyakorló parancsnoki rendszer}

A Rendvédelmi Tagozat szervezésében a tisztjelöltek az iskolaévek alatt folyamatosan bevonásra kerülnek a vezetői feladatokba, melynek fő színtere a hallgatói gyakorló parancsnoki rendszer. A felkészítés során minden hallgatónak el kell látnia valamilyen hallgatói parancsnoki szerepkört. Ekkor alakítható ki a hallgatókban az a vezetôi szemléletmód, hogy iskolatársának is feladatot szab, parancsnokként is gondoskodik róla. A

\footnotetext{
147 CZUPRÁK - KOVÁCS i. m. (2017). p. 71. alapján

148 ERDŐs Ákos et al.: i. m. (2019) pp. 96-97.

149 SZABÓ Andrea: Sub pondere crescit palma, avagy a pénzügyőr tisztjelölt erőpróbája. In: DOBÁK Imre HAUTZINGER Zoltán (szerk.): Szakmaiság, szerénység, szorgalom. Ünnepi kötet a 65 éves Boda József tiszteletére. Dialóg Campus Kiadó. Bp., 2018. p. 603.; és SZABÓ Andrea: A tisztjelölti jogállás sajátosságai. In: ERDŐs Ákos (szerk.): Integrált pénzügyőri ismeretek I. - Kezdő pénzügyőrök kézikönyve. Magyar Rendészettudományi Társaság Vám- és Pénzügyőri Tagozata, Bp., 2018. p. 162.
} 
gyakorló parancsnoki rendszer óriási előnye az, hogy a hivatására felkészülő tisztjelölt a kiképzés, a képzés, az oktatás és nevelés során megszerzett ismereteket közvetlenül a gyakorlatban tudja hasznosítani. Az évek alatt elsajátított stabil és széleskörű szakmai ismeretrendszer és az önismeret biztosítja a tisztjelölt képességét arra, hogy az adott szervezetet és közösséget vezetőként szolgálja, ezáltal már a kezdeti időszakban vezetőként is így szocializálódik.

\section{A „Vezetés- és szervezéselmélet” című tantárgy keretében végzett vezetői felkészítés}

A „Vezetés- és szervezéselmélet” olyan alapozó szakmai tantárgy, amely a Nemzeti Közszolgálati Egyem Rendészettudományi Kar Bûnügyi-, Bűnügyi igazgatási-, Rendészeti-, Rendészet igazgatási- alapképzési szakokon, nappali és levelező munkarendben kerül oktatásra a hallgatói felkészités negyedik és ötödik szemeszterében. A korábbi évek oktatási tapasztalatai alapján a tantárgy teljesítése a képzési időszak második felére helyeződött át, melynek oka az, hogy erre az idôszakra a hallgatók már sokkal „érettebbek és fogékonyabbak" a különböző vezetéselméleti ismeretek elsajátítására, hiszen a Rendvédelmi Tagozatnál eltöltött idő alatt vezetőként vagy vezetettként már tapasztalatokat szereztek, ezáltal jobban köthető a tananyag tartalma a tisztjelölti státuszhoz.

A tantárgy elsajátítása során elérendő kompetenciák közül kiemelendőek:

- Ismerje a közszolgálati szervezetek vezetés-irányítási rendszerét, a vezetés és szervezéselmélet legfontosabb összefüggéseit, az ehhez kapcsolódó elméleteket, fogalomrendszert, a problémamegoldás módszereit, rendelkezzen azzal a tudással, amelyek szükségesek a jövőbeni vezető-irányító feladatai végrehajtásához.

- Más szakterületekkel együttmúködve legyen képes múködtetni a hivatásrendjére jellemző szervezeteket, legyen jártas a tervezô, szervező, irányító munka végzésében. Rendelkezzen - szakterületéhez kapcsolódóan - megfelelő áttekintő-, rendszerező-, rendszerszemléletú képességgel.

- Ismerje az általa irányított szervezet feladatait és lehetôségeit, szervezeten belül- és kívül együttműködés rendszerét, legyen saját és szervezete tevékenységével szemben kritikus, követelménytámasztó, munkatársaival szemben empatikus, de feladat- és eredménycentrikus, törekedjen a kitűzött célok maradéktalan elérésére.

- Legyen képes az irányított szervezet munkáját önállóan, kellő felelősséggel tervezni, szervezni, irányítani, ellenôrizni, vezetôi útmutatásokat adni. ${ }^{150}$

\section{A „Vezetés-és szervezéselmélet” tantárgy oktatása és a föbb témakörök}

A tantárgy szerkezete és belső tartalma a tanszéki oktatói kollektíva által úgy került összeállításra, hogy az jelentősen hozzájárul a hallgatók vezetés- és szervezéselméleti szakmai felkészítéséhez, a vezetői tulajdonságok és ismeretek elméletben és gyakorlatban történő elsajátításához. A képzésben „a legújabb szervezés - és vezetéstani iskoláknak és kutatásoknak átfogó szemlélettel, integráltan és komolyabb hangsúllyal kell helyet kapniuk". ${ }^{151}$

\footnotetext{
${ }^{150}$ NKE Rendészettudományi Kar RRVTB01 Vezetés és szervezéselmélet tantárgyi program p. 2. Forrás: Rendészeti Vezetéstudományi Tanszék honlap. https://rtk.uni-nke.hu/document/rtk-uni-nkehu/RRVTB01 Vezetes es szervezeselemlet 20200217.pdf. (Letöltve: 2021.04.08.)

151 Nemzeti Közszolgálati Egyetem Intézményfejlesztési Terv 2015-2020. p. 25. https://www.uninke.hu/document/uni-nke-hu/IFT 170615 2020.pdf. (Letöltve: 2021.04.16.)
} 
A tantárgy jelenlegi tananyaga évek fejlesztő munkájának az eredménye, kiforrott ismeretanyagot tartalmaz, melyet a tantárgy elsajátításra vonatkozó hallgatói értékelések egyértelmű elégedettsége tükrözi. Maga a kurzus tananyaga a vezetéselmélet kialakulásával, a vezetéselmélet fejlődésének áttekintésével veszi kezdetét, tisztázásra kerülnek az alapfogalmak a vezetéselmélet fő kérdésfeltevései. A vezetés és a vezetők kérdéskörének áttekintése után a rendszerszemléletű vezetés kérdései, a vezetés- és szervezéstudomány kialakulása és fejlődése főbb alakjai kerülnek bemutatásra. Ezt követően a vezetéselmélet fő iskoláinak és irányzatainak az áttekintésére kerül sor, úgy, mint az empirikus iskola az eltárgyiasító iskola, a terrorizáló iskola, a pszichológiai irányzat, a szociológiai szemlélet és további irányzatok. A felkészítés során áttekintésre kerülnek a vezető személyiségével, vezetői stílusával, kommunikációjával kapcsolatos kérdések, az időgazdálkodás. Szó esik a korszerű vezetéstechnikai eszközök és módszerek alkalmazásáról a vezetés gyakorlatában.

A témaköröket minden esetben egy szemináriumi foglalkozás zárja, ahol az egyes szemináriumi csoportok létszáma maximum 15-20 fő. A szemináriumi foglakozás úgy zajlik le, hogy az elméleti jellegű elôadásokat megtartó oktató előzetesen kiadja a szemináriumi felkészülési kérdéseket a hallgatók számára, valamint meghatározza az egyes kiselőadások témáit. Ezt követően a hallgatók önállóan felkészülnek a szemináriumi foglalkozásokra. A szemináriumon az önként jelentkezők megtartják a kiselőadásukat, amit a csoport vita keretében feldolgoz és megvitat. A foglakozás következô részében a szemináriumi kérdések feldolgozásával (kérdés-felelet-értékelés) áttekintésre kerül az aktuális tananyagrészt lefedő tananyagtartalom.

A szóbeli ismétlő-értékelő rész után következik az elsajátított ismeretek írásbeli számonkérése, sor kerül a zárthelyi dolgozat megírására. A tantárgyi dokumentumok alapján, a Vezetés- és szervezéselmélet tantárgy értékelési rendszere az átlagosnál szigorúbb, a kérdésekre adott válaszok legalább 61\%-nak helyesnek kell lennie az elfogadható eredményhez. Ezt a követelményt a hallgatók megértették, hiszen csak szilárd tudás birtokában válhatnak eredményes vezetôvé.

Az első szemináriumot követően folytatódik a tananyag feldolgozása, áttekintésre kerül a vezetési folyamat, ezen belül a vezetési funkciók egyes elemeinek részletes feldolgozása, és értelmezése. Ez a témacsoport négy egymást követő foglalkozáson kerül feldolgozásra. Az első foglalkozás az információgyüjtés és tervezés, a tervezés folyamata a tervek típusai, tervezési modellek alkalmazása a gyakorlatban, megtörténik a parancsnoki munka elemeinek és vezetői funkcióknak az összevetése. Ezt követően a döntés előkészítés a döntési folyamat, a döntéselméleti megközelítések és módszerek feldolgozása következik. A harmadik foglalkozáson a szervezéssel kapcsolatos kérdések kerülnek áttekintésre. A szervezés, mint a döntés végrehajtása, a koordináció módszerei, területei, az irányítás és a szabályozás, a szervezés formái témakörök feldolgozása után következik az ellenőrzés témaköre, amely során a hallgatók megismerik annak célját, fajtáit, a külső-belső ellenőrzés funkcióit, fő elemeit, a vezető ellenőrzési feladatait, az ellenőrzési módszereket, a vezetői tevékenységek rendszerét a megfelelő vezetői hatékonyság biztosítása érdekében.

Ezt a tananyagegységet követi a témát lezáró újabb szeminárium, valamint a második zárthelyi dolgozat megírása.

A harmadik nagy témakör a szervezetek rendszerszemléletű megközelítése, ezen belül a szervezet és környezetének viszonya, a szervezetek kialakulása, általános jellemzői, lehetséges típusai, a szervezeti alapformák és a szervezetben alkalmazott koordinációs 
eszközök kerülnek áttekintésre. Ide tartoznak a hagyományos és a korszerű szervezet típusok is. Ezt követi a szervezeti hatalom kérdésköre, a szervezetfejlesztés, a munkatervezés és szervezés legfontosabb módszereinek feldolgozása. A témakörben a szervezeti kultúra egyes kérdései is tárgyalásra kerülnek, úgy, mint a hatalom, a szervezeti hatalom, a hatalmi erőtér, a vezetôkiválasztás kérdései, a szervezet munkájának hatékony irányítása és vezetése, a különböző szervezeti konfliktusok megoldási lehetőségei, a motiváció, a hatékony munkaszervezési módszerek a gyakorlatban, a szervezeti kultúra kialakulása szintjei. Ezt az előadás követi a szervezetek diagnosztizálása, a stratégiai tervezés, annak folyamata, valamint a projektmenedzsment témaköre. Ezt a témacsoportot is szeminárium követi, amely a „szokásos” módon zajlik le.

Az elméleti részek elsajátítását követően kezdetét veszi vezetői kompetenciák kialakítása címú foglalkozás, ahol a legjobb gyakorlatok kerülnek bemutatásra. A hallgatóknak különböző valós vezetéselméleti helyzetekben és szituációkban kell döntéseket hozniuk. Az adott döntési szituációk közül a hallgatók önállóan kiválasztanak egyet, döntésüket szóban, érvekkel, ellenérvekkel bizonyítják, amelyben utalniuk kell az elsajátított tananyagrészhez történő kapcsolódásra. Legtöbb kérdésben heves vita alakul ki a hallgatók között az egyes megoldásokat illetően, amelyet a foglakozás vezetője koordinál, terelve a résztvevőket az optimális megoldás irányába, ezzel is formálva a hallgatók vezetôi személyiségét. Ezeken a foglalkozásokon a szak-, szakirány szempontjából a legjellemzőbb esetek, tevékenységek kerülnek feldolgozásra.

A teljes vezetés és szervezéselméleti kurzust egy újabb szemeszter záró szemináriumi dolgozat zárja le, amelyben a félév során oktatott tananyagtartalom kerül áttekintésre. A tantárgyat szóbeli kollokvium zárja, melynek folyamatosan jó szintű eredményei azt bizonyítják, hogy a hallgatók megértik a tantárgy fontosságát, azt, hogy ezeket az ismereteket a vezető munkájuk során hasznosan kamatoztatni tudják.

\section{A „Közös közszolgálati gyakorlat” tantárgy oktatása és a főbb témakörök}

A Rendészeti Vezetéstudományi Tanszék által - az alapképzésben - oktatott tantárgyak közül kiemelkedik a „Közös közszolgálati gyakorlat” tantárgy, amely az egyetem minden alapképzésében megjelenik. A gyakorlatok folyamán történő vezetői felkészités, a vezetői kompetenciák fejlesztése a tanulmányi folyamatba beépített modulokon keresztül egyes képzési formák esetében több évtizedre nyúlik vissza. Lásd az alábbi publikációt. ${ }^{152}$ Már az 1990-es évek közepétől ezen gyakorlatok szervesen beépültek az oktatási programokba. ${ }^{153}$

A Nemzeti Közszolgálati Egyetemen a képzési dokumentumokban szerepel az „Egyetemi Közös Közszolgálati Gyakorlat” végrehajtása. Ennek a két napos gyakorlatnak a keretében a közszolgálat főbb hivatásrendjei a felkészítésük során elsajátított ismereteiket a valóságot megközelítő helyzethez igazodó gyakorlat során a mélyítik el. Magát a gyakorlatot elméleti foglakozássorozat előzi meg, amely a közszolgálati szemléletmód kialakítását, a feladatok közös megoldásának képességét fejleszti a hallgatókban.

A tantárgy tananyaga a különböző szervezetek ideiglenes vezetési rendszereit és az ahhoz kapcsolódó komplex ismeretrendszert tartalmazza. A gyakorlat végrehajtása során a vezetési

152 FÓRIZs Sándor: A századgyakorlat szerepe a tanszéki oktatásban. Nemzetvédelmi Egyetemi Közllemények, I. évf. 1997/2. sz. 1997. pp. 9-15.

${ }^{153}$ FÓRIzs Sándor: Mozzanatok és gondolatok a főiskolai szintű határôr tisztképzéshez. Határôrségi

Tanulmányok 1997/2. sz. 1997. pp. 26-34. 
rendszer kialakításával, időeltolódással, helyszín áthelyezésekkel, a gyakorló állomány aktív bevonásával egy komplex és minden évben változó témájú „Feladat” megoldása zajlik, modellezésre kerülnek a képzéseket megrendelő szervezetek és azok válságkezelési törzsei.

A „Közös közszolgálat gyakorlat” címú tantárgy elsajátítása során elérendő fontosabb kompetenciák közül a legjellemzőbbek:

- Rendelkezzen áttekintéssel a közszolgálati szervek vezetés-irányítási rendszeréről, az általánostól eltérő különleges viszonyok közötti vezetés rendjéről.

- Legyen képes együttmûködve múködtetni a normál múködési rendtől eltérô, különleges viszonyok között a hivatásrendjére jellemző szervezeteket. Ismerje a törzsmunkát, ahol aktív tervező, szervező, irányító feladatot tud végrehajtani.

- Saját és szervezete tevékenységével szemben legyen kritikus, követelménytámasztó, munkatársaival szemben empatikus, de feladat- és eredménycentrikus. ${ }^{154}$

\section{A Körös közszolgálati gyakorlat tantárgy oktatása és a föbb témakörök}

A tantárgy oktatásának célja, hogy a hallgatók felkészüljenek a saját és más hivatásrendek különleges viszonyok közötti feladatrendszeréből, megismerkedjenek a gyakorlat levezetésének általános rendjével, annak módszertanával.

A hallgatók az első előadáson képet kapnak a gyakorlat elgondolásának főbb elemeiről, a hallgatók által végrehajtandó feladatokról. Áttekintésre kerül a vezetés rendszere, a gyakorlat előkészítésében végzett tervező munka rendszere és tartalma, a katonai, rendészeti és közigazgatási vezetési modellek.

A következő foglakozásokon a hallgatók az egyes hivatásrendekhez kapcsolódóan (honvédség, rendvédelmi szervek, közigazgatási, államigazgatási szereplők) megismerkednek az ideiglenes törzsek összetételével, feladataival, a törzsbe beosztott szolgálati személyek felelősségi köreivel, feladataival, az együttműködő szervezetekkel történő kapcsolattartás és információcsere rendszerével, a törzs munkájának főbb elemeivel, a múveletek végrehajtásának rendszerével, a jelentések rendjével. Minden foglakozást az adott hivatásrend oktatója vezeti le a hallgatók számára, ezáltal biztosított a magas szintű szakmai hozzáértés.

A foglakozások sorában szerepel az egyezményes jelek, az együttmúködés alapjai címú témakör, amelynek során a hallgatók mindegyike elsajátítja az egyes együttműködésre kötelezett szervezetek által használt egyezményes jeleket és jelkulcsi ábrázolásokat.

Az elméleti felkészítést a gyakorlat helyzetbeállításának ismertetése követi. Feldolgozásra kerül a „Feladatban” szereplő, az aktuálisan kialakult konfliktus- és veszélyhelyzet kezelésében résztvevő nemzetközi és hazai szervezetek, szervek szerepe, feladata, hatósági jogköre, tevékenysége. A hallgatók a Moodle távoktatási rendszerben megkapják a „Közös Közszolgálati Feladat-ot” és a „A Kiegészítő Közös Közszolgálati Feladat-ot”, valamint megkapják a feldolgozásához szükséges útmutatást. A következő szemináriumon, immár a konkrétan kialakult konfliktus- és veszélyhelyzet kezelésében résztvevő szervezetek tevékenysége kerül modellezésre.

154 NKE Rendészettudományi Kar RRVTB06 Közös közszolgálati gyakorlat tantárgyi program p. 2. Forrás: Rendészeti Vezetéstudományi Tanszék honlap. Letöltés https://rtk.uni-nke.hu/document/rtk-uni-nkehu/RRVTB06 Kozos Kozszolgalati_Gyakorlat_20200217.pdf (Letöltve: 2021.04.08.) 
A tanórák keretében kerül levezetésre a két teljes napot magába foglaló „Közös Közszolgálati Gyakorlat". Az első napon a kialakult konfliktus- és veszélyhelyzet modellezése zajlik le, amely a veszélyhelyzet kihirdetésével zárul. A második gyakorlási napon a beállított „Feladat” alapján zajlik a fenyegető veszély elhárítása, majd azt az alkotmányos jogrend alap időszakának visszaállítása követi. A gyakorlaton minden hallgató tevékenysége mérésre kerül, amely a gyakorlati jegy alapját szolgáltatja. A hallgatók a gyakorlaton általában jó és kiváló szinten szerepelnek, a részvételük során mérhetően fejlődnek a kapcsolattartási, vezetési- és szervezési képességeik, kompetenciáik.

\section{Összefoglalás, javaslatok}

A kar minden oktatója tudatában van a felelősségének a tisztjelöltek felkészítése terén. A 2012. október 26-ai oktatói konferencián elhangzott „Belügyminiszteri ajánlások - Rektori feladatszabás a rendészeti tisztek felkészítésére" ${ }^{155}$ címú anyag kiemelten kezeli a vezetői felkészítés akkor aktuális, de ma is érvényben lévő feladatait. Mindezek alapján:

- A tisztjelölti felkészítés során az oktatók fokozott figyelmet fordítanak a vezetői készségek kialakítására és fejlesztésére, a parancsnoki ismeretek elmélyítésére, az állományról való gondoskodás témakörére.

- A hallgatói parancsnoki rendszer hasznosan szolgálja a hallgatók vezetői (parancsnoki) felkészítését.

- A rendészeti alapkiképzés rendszere, tananyagtartalma és módszertana kialakult, a tisztjelölti vizsga eredményei annak hatékonyságát bizonyítják.

- A vezetés- és szervezéselmélet tantárgy keretében oktatásra kerülnek a vezetéssel szemben támasztott követelmények, a vezetői tulajdonságok oktatása és kialakítása, a parancsnoki munka megtervezésének és megszervezésének gyakorlati fogásai, a sikeres vezetői tulajdonságok, a feladatok delegálásának rendje, módszerei, a munkaokmányok vezetése, a vezetôi fórumok rendszere, tartalma és módszerei.

- A Közös Közszolgálati Gyakorlatra történő felkészülés és az azon való részvétel, hatékonyan járul hozzá a vezetői felkészítéshez.

Az elért eredmények biztatók, a tisztjelöltek körében végzett, a különböző vezetői

képességek, készségek további fejlesztésére való törekvés továbbra is a kar kiemelt feladata.

\section{Felhasznált irodalom}

[1] BALLA József: A régi-új Határrendészeti Tanszéki Tanácsadó Testület, mint a megrendelői igények meghatározásának és támogatásának fóruma. Határrendészeti Tanulmányok, XIII. évfolyam 2016/1. szám. pp. 66-83.

[2] „Belügyminiszteri ajánlások - Rektori feladatszabás a rendészeti tisztek felkészítésére” (a 2012. október 26-ai oktatói konferencián elhangzott ajánlások - feladatok). Rendészeti Vezetéstudományi Tanszék irattár.

[3] CZuprák Ottó-Kovács Gábor: A szervezetvezetés elmélete. Dialóg Campus Kiadó Bp., 2017.

[4] ERDŐs Ákos et al.: Új generáció a rendészeti felsőoktatásban. In.: GAÁL Gyula HAUTZINGER Zoltán (szerk.): Gondolatok a rendészettudományról. Magyar Rendészettudományi Társaság, Bp., 2019. pp. 89-102.

155 „Belügyminiszteri ajánlások - Rektori feladatszabás a rendészeti tisztek felkészítésére” (a 2012. október 26ai oktatói konferencián elhangzott ajánlások - feladatok). Rendészeti Vezetéstudományi Tanszék irattár 1.6. és 2.2.1. pontok alapján. 
[5] FóRIZs Sándor: A századgyakorlat szerepe a tanszéki oktatásban. Nemzetvédelmi Egyetemi Közlemények. I. évf. 1997/2. sz. pp. 9-15.

[6] FÓRIZs Sándor: Mozzanatok és gondolatok a főiskolai szintű határőr tisztképzéshez. Határörségi Tanulmányok, 1997/2. sz. pp. 26-34.

[7] KovÁcs Gábor: A rendészeti szervezetekben lejátszódó vezetési folyamatok. Dialóg Campus Kiadó Bp., 2018.

[8] KOvÁCS István: Klasszikus vezetési funkciók a parancsuralmi rendszerben (állományvédelmi) ellenőrzés, és korrupciómegelőzés a helyi, és területi rendvédelmi szervek körében. Nemzeti Közszolgálati Egyetem, Bp., 2018. pp. 1-102.

[9] KovÁCs István: Vezetői státusz, és kommunikáció a parancsuralmi rendszerben, különös tekintettel a Rendőri Hivatás Etikai Kódexére, valamint a vezetési stílusokra a Lasswell modell alapján. Magyar Rendészetet, 18. évf. 2018/5. szám. pp. 177-196.

[10] NKE Rendészettudományi Kar RRVTB01 Vezetés és szervezéselmélet tantárgyi program p. 2. Forrás: Rendészeti Vezetéstudományi Tanszék honlap Letöltés: https://rtk.uni-nke.hu/document/rtk-uni-nkehu/RRVTB01 Vezetes es szervezeselemlet 20200217.pdf (Letöltve: 2021.04.08.)

[11] NKE Rendészettudományi Kar RRVTB06 Közös közszolgálati gyakorlat tantárgyi program p. 2. Forrás: Rendészeti Vezetéstudományi Tanszék honlap. https://rtk.uninke.hu/document/rtk-uni-nke-

hu/RRVTB06 Kozos Kozszolgalati Gyakorlat 20200217.pdf (Letöltve: 2021.04.08.)

[12] Nemzeti Közszolgálati Egyetem Intézményfejlesztési Terv 2015-2020. https://www.uni-nke.hu/document/uni-nke-hu/IFT 170615 2020.pdf (Letöltve: 2021.04.16.)

[13] SALLAi János: A magyar rendészeti képzés története 1922-2017. Rendőr altiszt (tiszthelyettes) és rendőrtiszt képzés a XX-XXI században. In: CZEne-Polgár Viktória - ZsÁmBOKINÉ FICSKOVSZKY Ágnes (szerk.) Mérföldkövek az adó- és vámigazgatás történetéből. Válogatott tanulmányok az évfordulók tükrében. Magyar Rendészettudományi Társaság Vám- és Pénzügyőri Tagozat, Bp., 2017. pp. 86-123.

[14] SALLAI János: Rendőr altiszt- és tisztképzés a m. kir állami rendőrségnél az államosítás (1920) után. In: Varga, János (szerk.) A határrendészeti tisztképzés negyedszázada. Dialóg Campus Kiadó, Bp., 2017. pp. 239-253.

[15] SZABÓ Andrea: Sub pondere crescit palma, avagy a pénzügyőr tisztjelölt erőpróbája. In: DOBÁK Imre - HAUTZINGER Zoltán (szerk.): Szakmaiság, szerénység, szorgalom. Ünnepi kötet a 65 éves Boda József tiszteletére. Dialóg Campus Kiadó. Bp., 2018.

[16] SZABÓ Andrea: A tisztjelölti jogállás sajátosságai. In: Erdős Ákos (szerk.): Integrált pénzügyőri ismeretek I. - Kezdő pénzügyőrök kézikönyve. Magyar Rendészettudományi Társaság Vám- és Pénzügyőri Tagozata. Bp., 2018.

\section{Lektor}

Fórizs Sándor, Prof., Dr., nyá. r. dandártábornok nyugállományú egyetemi tanár drforizs@gmail.com 